Original article

\title{
MOLECULAR CHARACTERISATION OF MULTIDRUG RESISTANT LACTOBACILLUS ISOLATED FROM DENTAL PLAQUE OF DOGS USING A MULTIPLEX PCR ASSAY
}

\author{
S. NOURI GHARAJALAR \\ Department of Pathobiology, Faculty of Veterinary Medicine, \\ Tabriz University, Tabriz, Iran
}

\section{Summary}

Nouri Gharajalar, S., 2018. Molecular characterisation of multidrug resistant Lactobacillus isolated from dental plaque of dogs using a multiplex PCR assay. Bulg. J. Vet. Med., 21, No 4, 436-444.

Dental caries is a significant public health problem in both humans and animals worldwide. Lactobacillus species have been reported to be highly prevalent in both superficial and deep caries. The aim of this study was to analyse the antibiotic resistance patterns of lactobacilli isolated from dog dental plaque samples. Thirty plaque samples were collected from dog teeth. All Lactobacillus isolates were identified using phenotypic and genotypic methods. Then, their antibiotic susceptibility patterns and genetic determinants responsible for antibiotic resistance were determined. Total of 17 isolates were identified as belonging to the genus Lactobacillus by both methods. The results of antibiotic susceptibility test showed that all isolates $(100 \%)$ were resistant to cefazolin and cefixime; $94 \%$ and $88 \%$ - resistant to penicillin and tetracycline; $64 \%, 58 \%, 52 \%$ and $41 \%$ of Lactobacillus isolates were resistant to amoxicillin-clavulanic acid, nitrofurantoin, vancomycin and chloramphenicol respectively. The results of resistance genes identification indicated that bla $_{T E M}$ was the most important determinant responsible for cefazolin, cefixime and amoxicillin-clavulanic acid resistance. The $m e c A$ gene was responsible for penicillin resistance while both tet $K$ and tet $M$ genes were equally involved in tetracycline resistance. According to the widespread resistance patterns seen among Lactobacillus isolates in this study, we concluded that antibiotic therapy for oral microbial infections should be used only where extremely needed.

Key words: antibiotic resistance, dental plaque, dog, Lactobacillus

\section{INTRODUCTION}

Dental plaque or biofilm is an adherent deposit of microbial communities (predominantly bacteria) and their products on tooth surfaces (Al-Mudallal et al., 2008). Bacterial plaques which accumulate on dental surfaces are amongst the first etiological agents of dental caries (Maripandi et al., 2011). Dental decay is a microbiologic infection of the tooth which is due to the dissolution of tooth mineral 
parts by acids derived from bacterial carbohydrate fermentation (Maripandi et al., 2011). The combination of genetic susceptibility factors, the presence of cariogenic bacteria like Streptococcus and Lactobacillus spp. and a source of fermentable carbohydrate leads to dental caries (Niemiec, 2011). Many dog owners are unaware that their pets may suffer from dental caries. Although the incidence of caries in dogs is lower than in humans, it does occur and we must watch for its reasons. According to studies, 5.25\% of adult canine patients had one or more caries lesion, usually bilaterally symmetrical. Also, pit and fissure caries are the most common types in dogs. The deep grooves on the buccal surface of the maxillary $4^{\text {th }}$ premolars and on the lingual side of the mandibular $1^{\text {st }}$ molars between the mesial and central cusps are among other sites at risk (Hale, 2009).

Lactobacilli usually isolated from dental caries, are amongst the pioneering microorganisms in dental decay progress (Karpinski et al., 2013). As a result the salivary Lactobacillus count is usually used in the caries prediction tests (Badet \& Thebaud, 2008). Lactobacillus bacteria are Gram-positive, usually non-motile, non-sporulating microorganisms that produce lactic acid as a major product of carbohydrates metabolism (Nair \& Surendran, 2005). Use of antimicrobial agents to eradicate diagnosed caries bacteria like Streptococcus mutans and Lactobacilli could reduce decay (Loesche, 1996). Cultural and biochemical methods can be used for identifying Lactobacillus genus but they sometimes lead to ambiguous results. On the other hand molecular methods are more exact and reliable for detection process (Roman-Mendez et al., 2009). Beta-lactam antibiotics including penicillins, cephalosporins and related compounds are active against many Grampositive, Gram-negative and anaerobic bacteria. They are usually used for treatment of oral diseases (Keith et al., 2000). Yet, incorrect antibiotic usage is one of the most important factors responsible for rise of bacterial resistance to commonly used antibiotics (Raum et al., 2007).

Today, molecular methods, especially PCR-based ones are preferentially used to determine antimicrobial resistance determinants (Leski et al., 2013). Clinical resistance of organisms to $\beta$-lactam antibiotics is associated with reduced permeation of the drugs through the outer cell membrane, inactivation of the compounds by $\beta$-lactamases, and the inability of the compounds to bind to target penicillin-binding proteins that have been changed (Moosdeen, 1997). Cephalosporin resistance in bacteria is often mediated by TEM- and SHV-type beta-lactamases. TEM-type and OXA-1 enzymes have the major role in amoxicillin-clavulanic acid resistance (Colom et al., 2003). Also, $b l a Z$ and mecA genes are specific for penicillin and oxacillin-like $\beta$-lactam antibiotic resistance (Kang et al., 2014).

There are many studies on dental caries in humans, but this problem is poorly studied in dogs. So the purpose of this study was to detect Lactobacillus prevalence in canine dental plaques and to identify their antimicrobial resistance genes.

\section{MATERIALS AND METHODS}

\section{Collection of samples}

Thirty plaque samples were collected from 4-8 years old German shepherd dogs, referred to Dr Onsori pet clinic, Urmia, Iran (2015). All samples were placed in sterile tubes containing $2 \mathrm{~mL}$ normal saline and homogenised (Al- 
Mudallal et al., 2008). Then homogenised samples were cultured on MRS agar (Sigma, USA) and incubated in $5 \% \mathrm{CO}_{2}$ at $37^{\circ} \mathrm{C}$ for $48-72 \mathrm{~h}$ (Nair et al., 2005).

Phenotypic identification of the genus Lactobacillus

The Gram reaction characteristics and cell morphology of all the isolates were examined using standard staining method. After confirming the Gram reaction, each isolate was further identified by biochemical tests like catalase, motility and nitrate reduction.

\section{Genotypic characterisation of Lactobacillus}

For molecular identification of lactobacilli to the genus level, all Lactobacillus isolates were cultured on MRS broth (Sigma, USA). The overnight cultures were applied for DNA extraction using Fermentase DNA extraction kit (Fermentase, Germany). Then extracted DNA was used as a template for identifying Lactobacillus. The PCR reaction was performed in a $25 \mu \mathrm{L}$ reaction mixture using DNA thermo-cycler (MWG AC BIOTECH THERMAL CYCLER, USA). A primer pair specific for $16 \mathrm{~s} / 23 \mathrm{~s}$ ribosomal RNA intergenic spacer region of Lactobacillus was used in the PCR reaction. Primer sequences were as followed: $\mathrm{F}$ : 5'-CTC AAA ACT AAA CAA AGT TTC- $3^{\prime}$ and R: 5-CTT GTA CAC ACC GCC CGT CA-3'. The reaction contents for each $25 \mu \mathrm{L}$ PCR consisted of $10 \mu \mathrm{L}$ Red Amp master mix $2 \times, 3 \mu \mathrm{L}$ of template DNA, $1 \mu \mathrm{L}$ of each primer and $10 \mu \mathrm{L}$ of deionised water. Cycling conditions comprised an initial denaturation step for $5 \mathrm{~min}$ at $95^{\circ} \mathrm{C}$, amplification: 20 cycles of $30 \mathrm{~s}$ at $95{ }^{\circ} \mathrm{C}, 30 \mathrm{~s}$ at $55^{\circ} \mathrm{C}$ and final $30 \mathrm{~s}$ at $72{ }^{\circ} \mathrm{C}$. The final extension step was for $7 \mathrm{~min}$ at $72{ }^{\circ} \mathrm{C}$. The reaction products were resolved on a $1 \%$ agarose gel. A 100 bp DNA ladder (Fermentase, Germany) was run on each gel as a size reference (Gad et al., 2014).

\section{Antimicrobial susceptibility testing}

Antibiotic susceptibility studies were performed by the standard disc diffusion method using the following antibiotics: tetracycline (30 $\mu \mathrm{g})$, chloramphenicol $(30 \mu \mathrm{g})$, penicillin (10 units), vancomycin $(30 \mu \mathrm{g})$, nitrofurantoin $(300 \mu \mathrm{g})$, cefixime $(5 \mu \mathrm{g})$, cefazolin $(30 \mu \mathrm{g})$, amoxicillinclavulanic acid $(20 / 10 \mu \mathrm{g})$. The results were interpreted as described in National Committee for Clinical Laboratory Standards guidelines (Ozgumus et al., 2007). Then the antibiotic resistance pattern of each isolate and the percentage of multiresistant bacteria were determined.

\section{Molecular detection of antibiotic resistance genes}

Genotypic analysis of antibiotic resistance was done through three multiplex PCR assays using universal primers (Table 1) following the procedures described below.

Isolates that were resistant to penicillin were subjected for PCR-base detection of $m e c A$ and blaZ genes. PCR amplification was carried out as follows: one cycle at $95{ }^{\circ} \mathrm{C}$ for $240 \mathrm{~s}, 30$ cycles $95{ }^{\circ} \mathrm{C}$ for $60 \mathrm{~s}$, $58{ }^{\circ} \mathrm{C}$ for $60 \mathrm{~s}$ and $72{ }^{\circ} \mathrm{C}$ for $60 \mathrm{~s}$ with a final extension period at $72{ }^{\circ} \mathrm{C}$ for $420 \mathrm{~s}$. After amplification, the PCR products were analysed on $2 \%$ agarose gel by electrophoresis and stained with safe dye for visualization (Kang et al., 2014).

Isolates that were resistant to cephalosporins and amoxicillin-clavulanate were subjected for PCR-base detection of bla $_{\text {TEM }}, b_{\text {bla }}$ SHV and bla $a_{O X A-1}$ genes. The PCR reaction consisted of initial denaturation at $94{ }^{\circ} \mathrm{C}$ for $5 \mathrm{~min}$, followed by 32 cycles at $94{ }^{\circ} \mathrm{C}$ for $30 \mathrm{~s}, 30 \mathrm{~s}$ of 
Table 1. Primer sequences used for PCR identification of mecA, blaZ, tetK, tetM, bla TEM, bla SHV and bla $O X A-1$ genes

\begin{tabular}{|c|c|c|}
\hline Primer & Gene & Sequences \\
\hline Forward & $m e c A$ & 5/ AAA ATC GAT GGT AAA GGT TGG C- 3 \\
\hline Reverse & mecA & $5^{\prime}-$ AGT TCT GCA GTA CCG GAT TTG C- $3^{\prime}$ \\
\hline Forward & blaZ & $5^{\prime}-$ TGA CCA CTT TTA TCA GCA ACC- $3^{\prime}$ \\
\hline Reverse & blaZ & $5^{\prime}-$ GCC ATT TCA ACA CCT TCT TTC- $3^{\prime}$ \\
\hline Forward & bla ${ }_{T E M}$ & $5^{\prime}-$ ATC AGC AAT AAA CCA GC- $3^{\prime}$ \\
\hline Reverse & bla ${ }_{T E M}$ & $5^{\prime}-$ CCC CGA AGA ACG TTT TC- $3^{\prime}$ \\
\hline Forward & bla $_{S H V}$ & $5^{\prime}$ - AGG ATT GAC TGC CTT TTT G- $3^{\prime}$ \\
\hline Reverse & $b_{\text {la }}{ }_{S H V}$ & $5^{\prime}-$ ATT TGC TGA TTT CGC TCG- $3^{\prime}$ \\
\hline Forward & bla OXA-1 & $5^{\prime}-$ ATA TCT CTA CTG TTG CAT CTC C- $3^{\prime}$ \\
\hline Reverse & bla OXA-1 & $5^{\prime}-$ AAA CCC TTC AAA CCA TCC- $3^{\prime}$ \\
\hline Forward & tet $K$ & $5^{\prime}-$ GTA GCG ACA ATA GGT AAT AGT- $3^{\prime}$ \\
\hline Reverse & tet $K$ & $5^{\prime}$ - GTA GTG ACA ATA AAC CTC CTA- $3^{\prime}$ \\
\hline Forward & tetM & $5^{\prime}-$ AGT GGA GCG ATT ACA GAA- $3^{\prime}$ \\
\hline Reverse & tetM & 5'- CAT ATG TCC TGG CGT GTC TA- $3^{\prime}$ \\
\hline
\end{tabular}

annealing at $54{ }^{\circ} \mathrm{C}, 1 \mathrm{~min}$ of extension at $72{ }^{\circ} \mathrm{C}$ with final extension step at $72{ }^{\circ} \mathrm{C}$ for $10 \mathrm{~min}$. Amplified samples were submitted to $2 \%$ agarose gel electrophoresis and stained by safe dye (Colom et al., 2003).

Finally the isolates that were resistant to tetracycline were subjected for PCRbase detection of tet $K$ and tet $M$ genes which were responsible for tetracycline resistance. The PCR program was as followed: $3 \mathrm{~min}$ of initial denaturation, 30 cycles of amplification at $94{ }^{\circ} \mathrm{C}$ for $30 \mathrm{~s}, 55^{\circ} \mathrm{C}$ for $30 \mathrm{~s}$ (annealing) and $72{ }^{\circ} \mathrm{C}$ for $30 \mathrm{~s}$. The 4-min final extension was carried out at $72{ }^{\circ} \mathrm{C}$. The PCR products were analysed by electrophoresis on $1.5 \%$ agarose gel (Strommenger et al., 2003).

\section{RESULTS}

Isolation and identification of Lactobacillus bacteria

A total of 17 Lactobacillus (56.6\%) isolates were recovered from the $30 \mathrm{dog}$ dental plaques samples. Using Gram staining, all 17 isolates were purple coloured
Gram positive rods under light microscopy. They were non-motile, catalase negative bacteria with no ability to reduce nitrate.

The molecular identification of Lactobacillus to the genus level was done using PCR assay. When a DNA from the Lactobacillus isolates was used as a template, a $250 \mathrm{bp}$ band was obtained on agarose gel under UV light (Fig. 1). By combination of both biochemical and molecular identification, it was found that bacteria belonging to Lactobacillus genus wererecovered from $56.6 \%$ of dog dental plaque samples.

\section{Antibiotic susceptibility results}

From 17 Lactobacillus isolates, 16 (94\%) were multiresistant, all of them resistant to cefazolin and cefixime, 16 (94\%) were resistant to penicillin, $15(88 \%)$ were tetracycline-resistant, $11(64 \%)$ of the Lactobacillus were amoxicillin-clavulanate resistant. Ten (58\%), 9 (52\%) and 7 $(41 \%)$ isolates were resistant to nitrofurantoin, vancomycin and chloramphenicol, respectively. 
Molecular characterisation of multidrug resistant Lactobacillus isolated from dental plaque of dogs ....

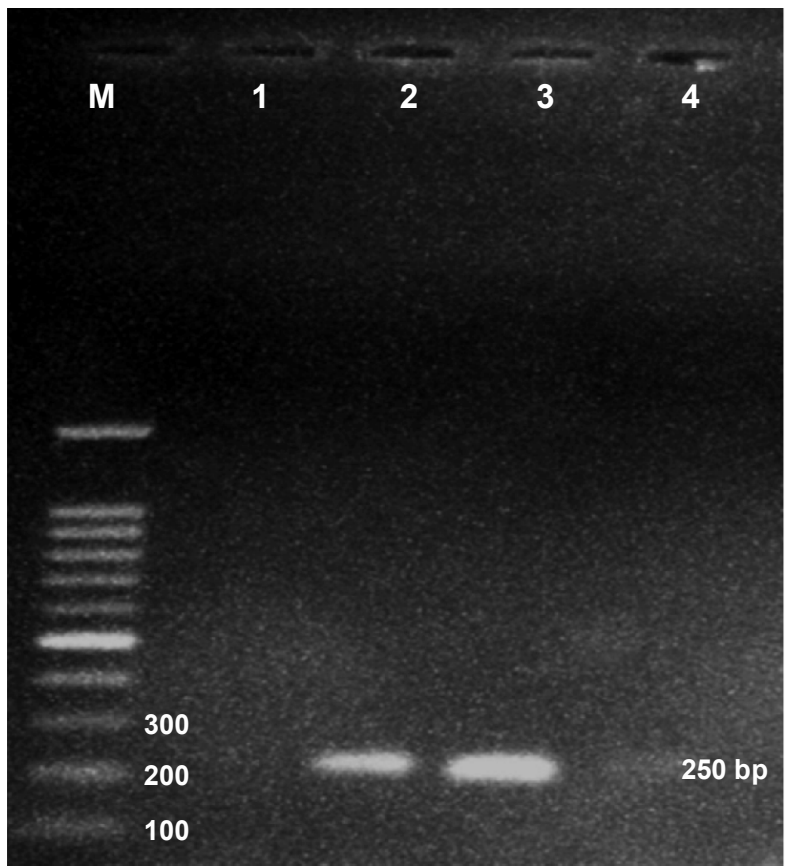

Fig. 1. 16s/23s rRNA intergenic spacer region gene found at $250 \mathrm{bp}$ on $1 \%$ agarose gel after PCR amplification. Lane M - 100 bp ladder marker; lane 1 - negative control; lane 2 - positive control; lane 3 -Lactobacillus 16s/23s rRNA intergenic spacer region gene found at $250 \mathrm{bp}$.

\section{Resistance determinant identification}

All 16 penicillin-resistant lactobacilli, had the 532 bp band indicative of $m e c A$ gene. None of the isolates exhibited the blaZ gene. Therefore, the $m e c A$ determinant was the major gene responsible for penicillin resistance (Fig. 2).

Among the cefazolin and cefixime resistant lactobacilli, all generated fragments of $516 \mathrm{bp}, 11(64 \%)$ generated 619 bp and $6(35 \%)$ had 392 bp bands on agarose gel electrophoresis, which were indicative of bla $a_{\text {TEM }}(516 \mathrm{bp})$, bla $a_{\text {OXA-I }}$ (619 bp) and bla ${ }_{S H V}(392 \mathrm{bp})$. So the bla $_{T E M}$ gene was the most important determinant responsible for cefazolin and cefixime resistance (Fig. 3). Also, 58\% of Lactobacillus isolates were resistant to amoxicillin-clavulanate and $b l a_{T E M}$ was probably the first important gene about this resistance pattern, followed by bla $a_{S H}$ gene (Fig. 3).

All 15 tetracycline-resistant lactobacilli had 360 and 158 bp bands indicative of tet $K$ and tet $M$ genes confirming that both genes had the same role in tetracycline resistance (Fig. 4).

\section{DISCUSSION}

Dental plaque or biofilm which develops on oral tissues is a complex organisation which remains stable with time despite regular environmental changes. Whenever the balance among indigenous bacteria is compromised, dental caries could appear (Badet \& Thebaud, 2008). Lactobacillus 


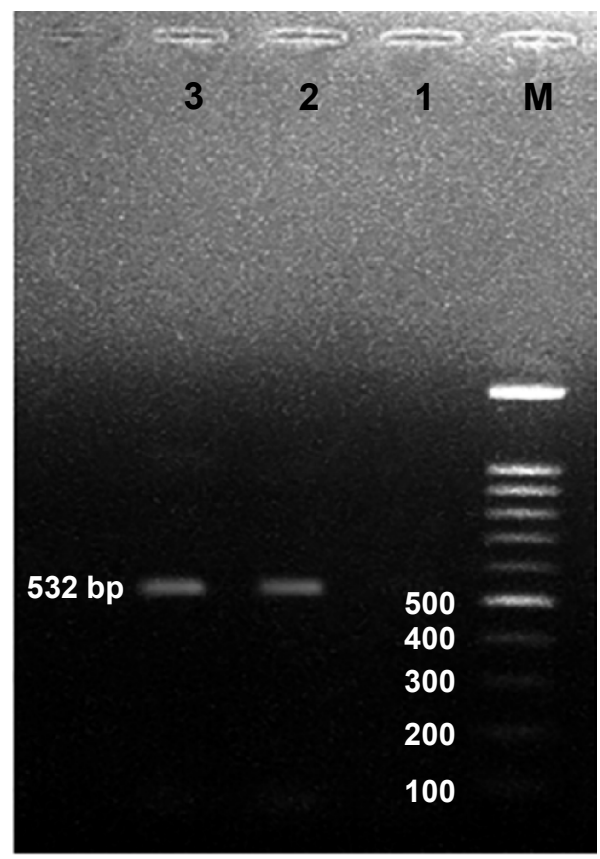

Fig. 2. Agarose gel of PCR product from $\mathrm{Lac}$ tobacillus isolates, using primer group for $m e c A$ and blaZ. Lane $\mathrm{M}-100$ bp ladder; lane 1 - negative control; lane 2 - positive control; lane $3-m e c A$ gene found at $532 \mathrm{bp}$.

species have been consistently associated with dental decay and are one of the most important secondary pathogens in dental carries (Daniyan \& Abalaka, 2011). The ecology of Lactobacilli in the oral cavity was studied (Badet \& Thebaud, 2008). According to their literature, lactobacilli are the first microorganisms implicated in dental caries development. Some authors have also noticed an increase in the percentage of Lactobacillus before the onset of carious lesions. Our study results also indicated that lactobacilli had important role in dental plaque which could lead to dental caries.

Identification of Lactobacillus bacteria according to phenotypic methods like culture and biochemical tests is difficult because sometimes needs determination of

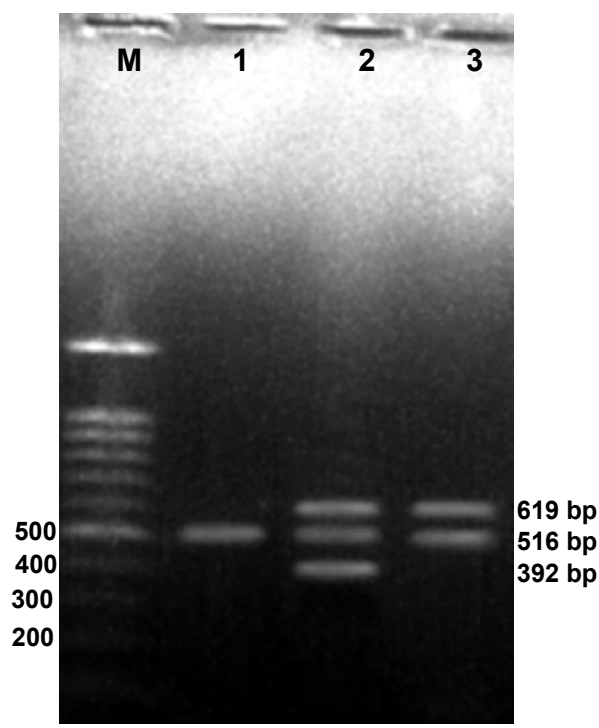

Fig. 3. Gel electrophoresis of the PCR products of bla $a_{T E M}, b l a_{S H V}$ and bla $a_{O X A-I}$ resistance determinants. Lane $\mathrm{M}-100 \mathrm{bp}$ ladder; lane 1 - $\operatorname{bla}_{\text {TEM }}(516 \mathrm{bp})$; lane 2 - bla $a_{\text {TEM }}(516 \mathrm{bp})$, bla $a_{O X A-I}(619 \mathrm{bp})$ and $b l a_{S H V}(392 \mathrm{bp})$; lane 3 $b l a_{T E M}(516 \mathrm{bp})$ and $b l a_{O X A-I}(619 \mathrm{bp})$.

bacterial characteristics beyond those of popular tests (Dickson et al., 2005). Molecular methods are generally more reliable in Lactobacillus identification process. A novel species-specific PCR assay was used for identifying Lactobacillus fermentum in human supragingival plaque (Dickson et al., 2005). They concluded that PCR assay provides more rapid and sensitive alternative to culture methods in Lactobacillus identification. In this study we also used both phenotypic and genotypic methods for Lactobacillus detection. All phenotypically detected isolates were also further confirmed using PCR based assay.

Selective pressure of antibiotics usage in both human and veterinary treatments and also spreading of antibiotic resistant microorganisms has aggravated acquisi- 
tion and dissemination of resistant genes. The prevalence and susceptibility patterns of bacterial isolates from human dental caries was studied (Daniyan et al., 2011). All Lactobacillus strains in their study were resistant to chloramphenicol, nitrofurantoin and tetracycline but only $41 \%$ of our Lactobacillus isolates were resistant to chloramphenicol, $58 \%$ were resistant to nitrofurantoin and $88 \%$ were tetracycline resistant. On the other hand the most frequent resistance pattern was against cefazolin and cefixime antibiotics (100\%).

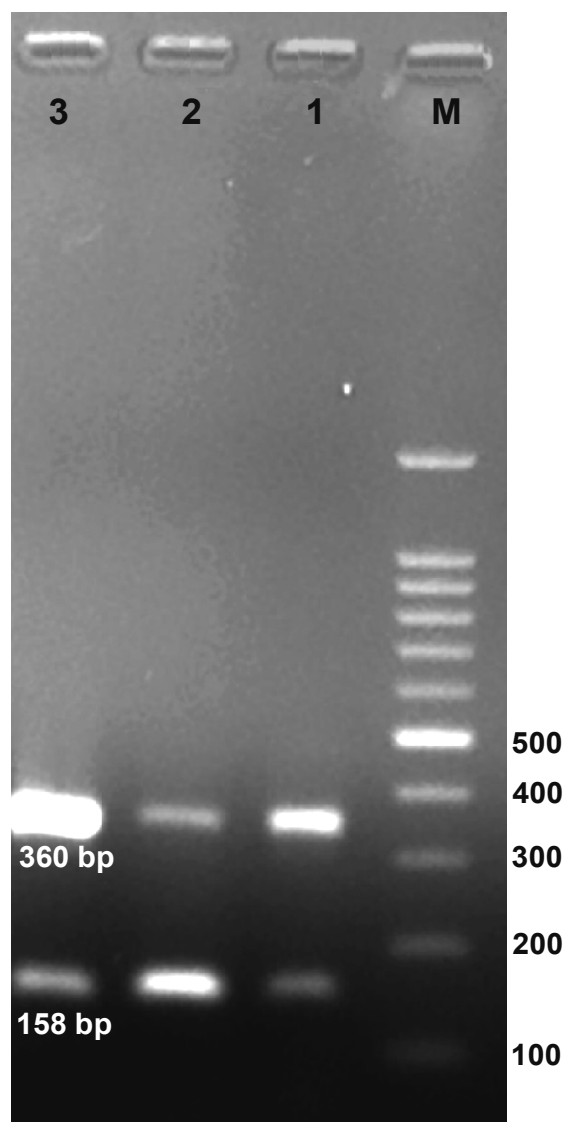

Fig 4. PCR detection of tet $K$ and tetM markers in Lactobacillus isolates. Lane $\mathrm{M}-$ 100 bp ladder marker; lane 1 -positive control; lanes 2,3 - tetK (360 bp) and tetM (158 bp).
Studies on targeted isolation of bacterial species associated with canine periodontal health or disease from dental plaque were performed by Davis et al. (2014). They used quantitative polymerase chain reaction approach for bacterial screening process and concluded that their approach could be applied to any uncultured bacterial species where knowledge about their environmental requirements is low.

Fayaz et al. (2014) also determined prevalence and antibiotic susceptibility patterns of dental biofilm forming bacteria in humans. All Lactobacillus species isolated in their study were resistant to chloramphenicol, tetracycline, and gentamicin. In our research, however, the commonest resistance pattern was against cephalosporins followed by penicillin. Resistance to tetracycline was on the third place and that to chloramphenicol was the least common pattern identified among our Lactobacillus isolates.

Tetracycline-resistant bacteria constituted an average of $11 \%$ of all cultivable oral microflora (Villedieu et al., 2003). The most common identified tet gene was tet $M$ but the frequency of tet $K$ gene was low. In this study, the prevalence of both tet $K$ and tet $M$ genes among the isolates was very high.

Binta \& Patel (2016) screened $\beta$-lactamase producing oral anaerobic bacteria and the presence of $c f x A$ and bla $_{T E M}$ genes that are responsible for resistance to $\beta$ lactam antibiotics. Fifty one percent of the isolates carried $c f x A$ while none carried $b l a_{T E M}$ gene. In this study bla $_{T E M}$ was the most important determinant responsible for resistance to $\beta$-lactam antibiotics. Also, Koukos et al. (2016) studied the prevalence of $b l a_{\mathrm{TEM}}$ and nim resistance genes in isolates from the oral cavity of Greek subjects and established that $b l a_{\mathrm{TEM}}$ 
gene was found in $36 \%$ of the isolates but the nim gene was not detected in any of the samples. According to our results $64 \%$ of isolates carried the bla $a_{\mathrm{TEM}}$ gene. Antibiotic resistance genes in Staphylococcus aureus isolated from the oral cavity of Tunisian children (Zmantar et $a l ., 2012)$ demonstrated that the frequency of blaZ gene among strains was $100 \%$. On the contrary, in our study, none of the isolates had the blaZ gene

According to the results of this study, we concluded that antibiotics should be used when extremely needed for control and treatment of infections. They inappropriate use results in persistence and dissemination of multidrug resistant bacteria in human and animal hosts.

\section{ACKNOWLEDGEMENTS}

This work was financially supported by the Tabriz University.

\section{REFERENCES}

Al-Mudallal, N. H. A., E. F. A. Al-Jumaily, N. A. A. Muhimen \& A. W. Al- Shaibany, 2008. Isolation and identification of mutans streptococci bacteria from human dental plaque samples. Journal of Al-Nahrain University, 11, 98-105.

Badet, C. \& N. B. Thebaud, 2008. Ecology of Lactobacilli in the oral cavity: A review of literature. The Open Microbiology Journal, 2, 38-48.

Bhardwaj, A., M. Puniya, K. P. S. Sangu, S. Kumar \& T. Dhewa, 2012. Isolation and biochemical characterization of Lactobacillus species isolated from Dahi. Research \& Reviews: A Journal of Dairy Science and Technology, 1, 1-12.

Binta, B. \& M. Patel, 2016. Detection of $c f x A 2, c f x A 3$, and $c f x A 6$ genes in betalactamase producing oral anaerobes.
Journal of Applied Oral Science, 24, 142 147.

Colom, K., J. Perez, R. Alonson, A. Fernandez-Aranguiz, E. Larino \& R. Cisterna, 2003. Simple and reliable multiplex PCR assay for detection of blaTEM, bla SHV and blaOXA-1 genes in Enterobacteriaceae. FEMS Microbiology Letters, 223, 147-151.

Daniyan, S. Y. \& M. E. Abalaka, 2011. Prevalence and susceptibility pattern of bacterial isolates of dental caries in a secondary health care institution, Nigeria. Shiraz E-Medical Journal, 12, 135-139.

Davis, I. J., C. H. Bull, A. Horsfall, I. Morley \& S. Harris, 2014. The unculturables: Targeted isolation of bacterial species associated with canine periodontal health or disease from dental plaque. $B M C$ Microbiology, 14, 196.

Dickson, E. M., M. P. Riggio \& L. Macpherson, 2005. A novel species specific PCR assay for identifying Lactobacillus fermentum. Journal of Medical Microbiology, 54, 299-303.

Fayaz, M., P. K. Sivakumaar \& M. Melvin Joe, 2014. Prevalence and antibiotic susceptibility pattern of dental biofilm forming bacteria. International Journal of Current Microbiology and Applied Sciences, 3, 46-50.

Gad, G. F. M., A. M. Abdel-Hamid \& Z. S. H. Farag, 2014. Antibiotic resistance in lactic acid bacteria isolated from some pharmaceutical and dairy products. Brazilian Journal of Microbiology, 45, 25-33.

Hale, F. A., 2009. Dental caries in the dog. Veterinary Dentistry, 50, 1301-1304.

Kang, M. H., M. J. Char, J. W. Yoon, S. G. Kim, S. Y. Lee, J. H. Yoo \& H. M. Park, 2014. Antibiotic resistance and molecular characterization of ophthalmic Staphylococcus pseudintermedius isolates from dogs. Journal of Veterinary Science, 15, 409-415.

Karpinski, T. M. \& A. K. Szkaradkiewicz, 2013. Microbiology of dental caries. Jour- 
Molecular characterisation of multidrug resistant Lactobacillus isolated from dental plaque of dogs ....

nal of Biology and Earth Science, 3, 2124.

Keith, B., M. D. Holten \& E. M. Onusko. 2000, Appropriate prescribing of oral betalactam antibiotics. American Family Physician, 62, 611-620.

Koukos, G., A. Konstantinidis, L. Tsalikis, M. Arsenakis, T. Slini \& D. Sakellari. 2016, Prevalence of $\beta$-lactam $\left(b l a_{\mathrm{TEM}}\right)$ and metronidazole (nim) resistance genes in the oral cavity of Greek subjects. The Open Dentistry Journal, 10, 89-98.

Leski, T. A., G. J. Vora, B. R. Barrow, G. Pimentel, B. L. House, M. Ncklasson, M. Wasfy, M. Abdel-Maksoud \& C. R. Taitt, 2013. Molecular characterization of multidrug resistant hospital isolates using the antimicrobial resistance determinant microarray. PLOS One, $\mathbf{8}, 1-12$.

Loesche, W. J., 1996, Medical Microbiology, $4^{\text {th }}$ edn, University of Texas Medical branch at Galveston.

Maripandi, A., A. Kumar \& A. Al Salamah, 2011. Prevalence of dental caries bacterial pathogens and evaluation of inhibitory concentration effect on different tooth pastes against Streptococcus spp. African Journal of Microbiology Research, 5, 1778-1783.

Moosdeen, F., 1997. The evolution of resistance to cephalosporins. Clinical Infectious Diseases, 24, 487-493.

Nair, P. S. \& P. K. Surendran, 2005. Biochemical characterization of lactic acid bacteria isolated from fish and prawn. $\mathrm{Bra}$ zilian Journal of Microbiology, 4, 48-52.

Niemiec, B. A., 2011. Small Animal Dental, Oral and Maxillofacial Disease: A Colour Handbook, $2^{\text {nd }}$ edn, Kindle Edition, 133.

Ozgumus, O. B., E. Celik-Sevim, S. Alpay Karaoglu, C, Sandalli \& A. Sevim, 2007. Molecular characterization of antibiotic resistant Escherichia coli strains isolated from Tap and Spring Waters in a coastal Region in Turkey. The Journal of Microbiology, 45, 379-387.
Raum, E., S. Lietzau, H. V. Baum, R. Marre \& H. Brenner, 2007. Changes in Escherichia coli resistance patterns during and after antibiotic therapy: A longitudinal study among outpatients in Germany. Clinical Microbiology and Infection, 14, 41-48.

Roman-Mendez, C., C. Badet, A. Yanez, M. L. Dominguez, S. Giono, B. Richard, J. Nancy \& G. Dorignac, 2009. Identification of oral strains of Lactobacillus species isolated from Mexican and French children. Journal of Dentistry and Oral Hygiene, 1, 9-16.

Strommenger, B., C. H. Kettlitz, G. Werner \& W. Witte, 2003. Multiplex PCR assay for simultaneous detection of nine clinically relevant antibiotic resistance genes in Staphylococcus aureus. Journal of Clinical Microbiology, 41, 4039-4094.

Villedieu, A., M. L. Diaz-Torres, N. Hunt, R. McNab, D. A. Spratt, M. Wilson \& P. Mullany, 2003. Prevalence of tetracycline resistance genes in oral bacteria. Antimicrobial Agents and Chemotherapy, 47, 878-882.

Zmantar, T., B. Kouidhi, H. Hentati \& A. Bakhrouf, 2012. Detection of disinfectant and antibiotic resistance genes in Staphylococcus aureus isolated from the oral cavity of Tunisian children. Annals of Microbiology, 62, 123-128.

Paper received 07.12.2016; accepted for publication 07.04.2017

\section{Correspondence:}

S. Nouri Gharajalar Department of Pathobiology, Faculty of Veterinary Medicine, 5166 Tabriz University, 616471 Tabriz, Iran. cell number: 00989141468635 e-mail: saharnouri@yahoo.com 